\title{
架構式プレキャスト工法による大規模店舗の省力化施工 ョッパーズプラザ横須賀
}

川辺 知道*1 ・稲冨 健彦*2 ・吉野 次彦*3 $・$ 小早川 敏*4

\begin{abstract}
概 要 $\mathrm{RC}$ 造軸組工法の工業化施工を対象としたプレキャスト工法, FRPC 工法の施工実績はすでに 30 件を超えて いる。本工事においては，FRPC 工法の採用にあたって，工法全体の見直しを行い，部材の製造方法，非構造材の PCa 化, 品質管理方法などの検討を行った。部材製造方法は, サイト工場と固定工場の併用により, 工期の短縮, 製造コスト 低减などに大きな成果を得た。この報告は, 部材製造における労務分析結果, 非構造材の PCa 化の施工例, 施工性を確 認するための種々の測定結果について紹介する。

キーワード : 架構式プレキャスト, サイト工場, 歩脚り, 品質管理
\end{abstract}

\section{1.はじめに}

三浦半島の入口に位置する横須賀市は, かつて, 日本 の一流ジャズミュージシャンが巣立っていった街でもあ り, 今また, 三浦半島随一の快適都市として, 行政, 民 間企業，市民の一致協力による新しい街づくり，横須賀 市臨海部都市整備計画が始まっている。

その開発の一つとして臨海公園と三笠公園を結ぶ 1 万 $\mathrm{m}$ 臨海プロムナード計画があり, このプロムナードの 中心に位置する, カルチャー施設を含む大型店舗 “ショッパーズプラザ横須賀”が, 1991 年 4 月 25 日オー プンした。

本建物は核店舗（スーパーマーケット）を中心とし て, 専門店・飲食店・オフィス・スポーツ・レジャー施 設等が配置され, 建物屋内外に 1600 台駐車可能な施設 を併設している。

本建物は事業主が 2 つに分かれており, 工事区分, 躯 体の施工方法はそれぞれ異なるが，建物全体は一体とし て使用されている。

本報告は, 架構式プレキャスト工法 (FRPC 工法) で 施工した工事区分のうち, 主にプレキャスト部材の製造

*1 かわべ・ともみち/(株)フジ夕 横浜支店 建築工事部 長代理

*2 いなとみ・たけひこ/同上＼cjkstart横浜支店 ヨコスカ $\mathrm{S}$ W作業所 副所長

*3 よしの・つぐひこ／同上技術研究所 主任研究 員(正会員)

*4 こばやかわ • さとし/同上 建築本部 技術部 技師 長
と品質管理について述べるものである。

\section{2. 工 事 概 要}

本建物は, 全建築面積 : 2 万 $7281.24 \mathrm{~m}^{2}$, 全延床面 積 : 12 万 $1281 \mathrm{~m}^{2}$ である。建物全景を写真-1に示 す。

この建物のうち, 本荘エリアの建物概要を下記に, 全 体配置図を図-1に，建物の基準階平面および立面図を 図一2, 図-3 に示す。

工事名称 : (仮称) ヨコスカシーウィンドウ新築工事 所 在 地 : 神奈川県横須賀市本町 2-1-12

構造規模: $\mathrm{RC}$ 造 (一部 $\mathrm{SRC}$ 造) $5 \mathrm{~F}$ 敷地面積 : 3 万 $4151 \mathrm{~m}^{2}$ (全体 4 万 $9334 \mathrm{~m}^{2}$ ) 建築面積 : 2 万 $474 \mathrm{~m}^{2}$ (全体 2 万 $7865 \mathrm{~m}^{2}$ ) 延床面積 : 8 万 $5634 \mathrm{~m}^{2}$ (全体 12 万 $1281 \mathrm{~m}^{2}$ ) 建物高さ : 軒高 $24.2 \mathrm{~m}$, 最高部高さ $40.02 \mathrm{~m}$ 工 期 : 1989. 9.9 1991.4.23 (19 か月)

3. 施工計画

\section{1 工法 概 要}

本建物は企画設計の段階から FRPC 工法による施工 を前提としたうえで計画を推進した。

FRPC 工法とは架構式プレキャスト（以下, プレキャ ストを $\mathrm{PCa}$ と略す) 構造で, 基礎ばり, 柱, はり, 小 ばりなど, すべての部材を単一材として, 各部材はあと 打ちコンクリートを介して一体とする工法である。

また，床はフル PCa 板を用いる場合と，ハーフ PCa 板（合成床板）を用いる場合とがあり, 設計条件, 用途 


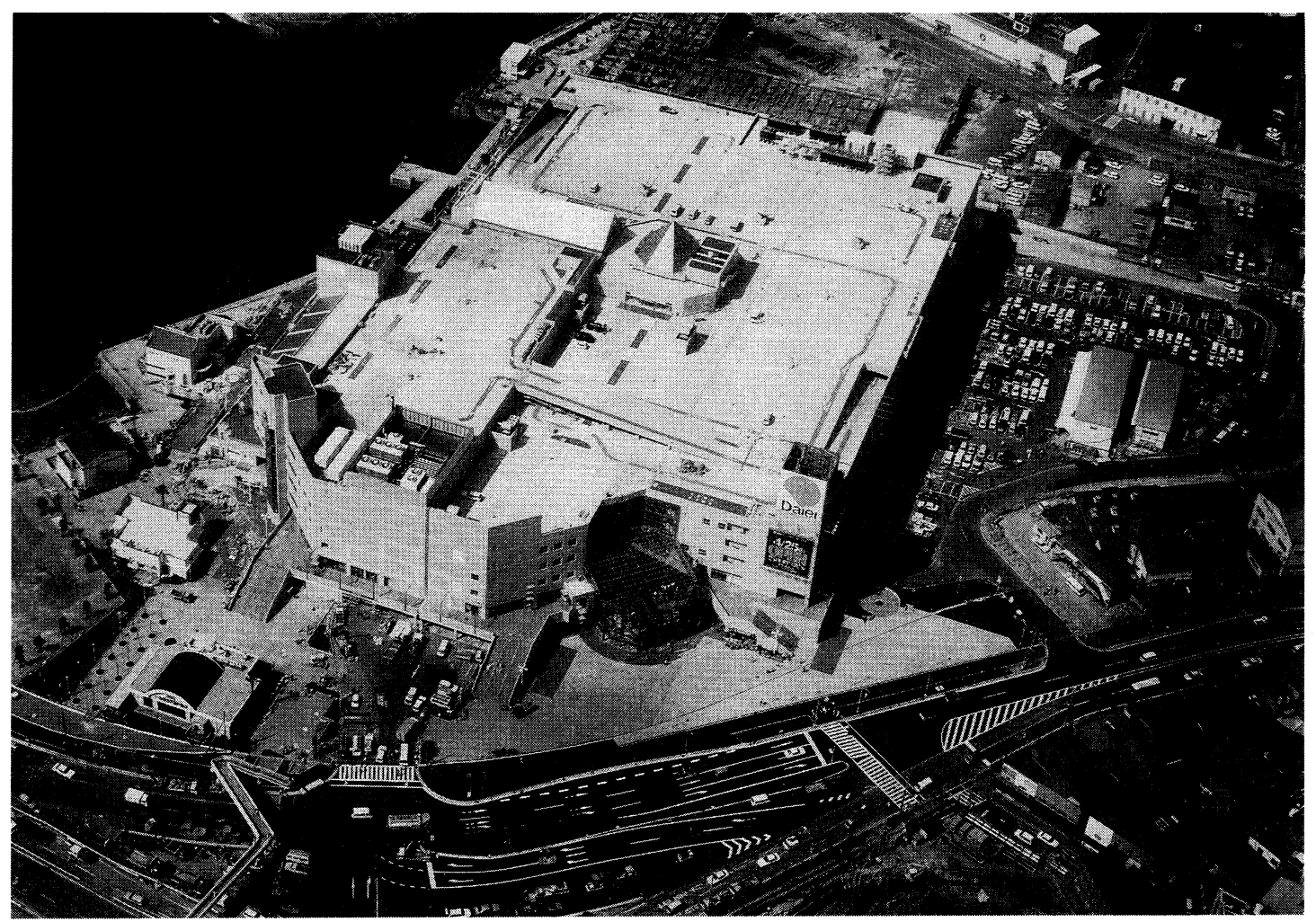

写真-1 建物全景

\section{Application of the Fujita Reinforced Precast Concrete (FRPC) Method to a Large Scale Shopping Complex -Shoppers Plaza Yokosuka-}

By T. Kawabe, T. Inatomi, T. Yoshino and S. Kobayakawa

Concrete Journal, Vol. 29, No. 9, pp. 38〜47, Sept. 1991

Synopsis Fujita Corporation has developed its own reinforced precast concrete system (FRPC) to facilitate site erection of reinforced concrete frames. The system has been successfully applied to more than 30 large projects. For this project, Fujita reviewed the entire FRPC system with particular attention to, (1) organization of the manufacturing method. (2) application of the FRPC system to secondary structural members, for example balconies, as well as the main structural frame. (3) quality control procedures. Manufacture of the precast members was carried out at both a permanent precast plant and at a site plant which resulted in substantial time and cost savings. This paper presents Fujita's observations on (1) comparative labour productivity at the two production plants. (2) application of the FRPC system to secondary structural members by reference to actual examples. (3) quality control from detailed monitoring and testing during and after manufacture and erection.

Keywords : precast reinforced concrete frame, site plant, productivity, quality control 


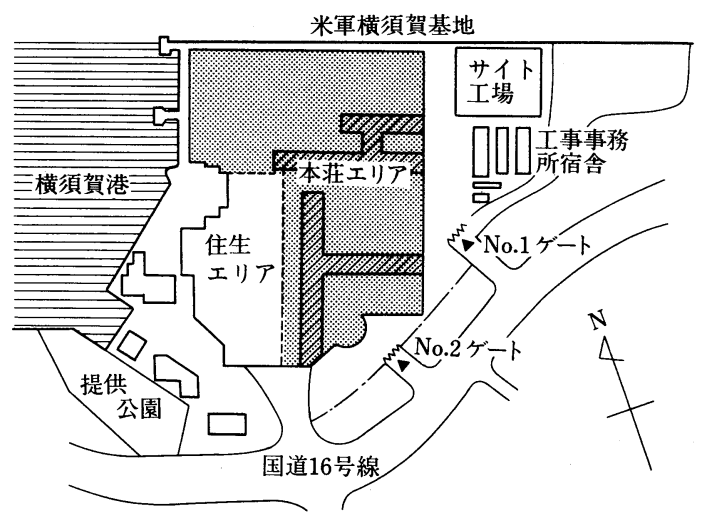

図一1 全体配置図
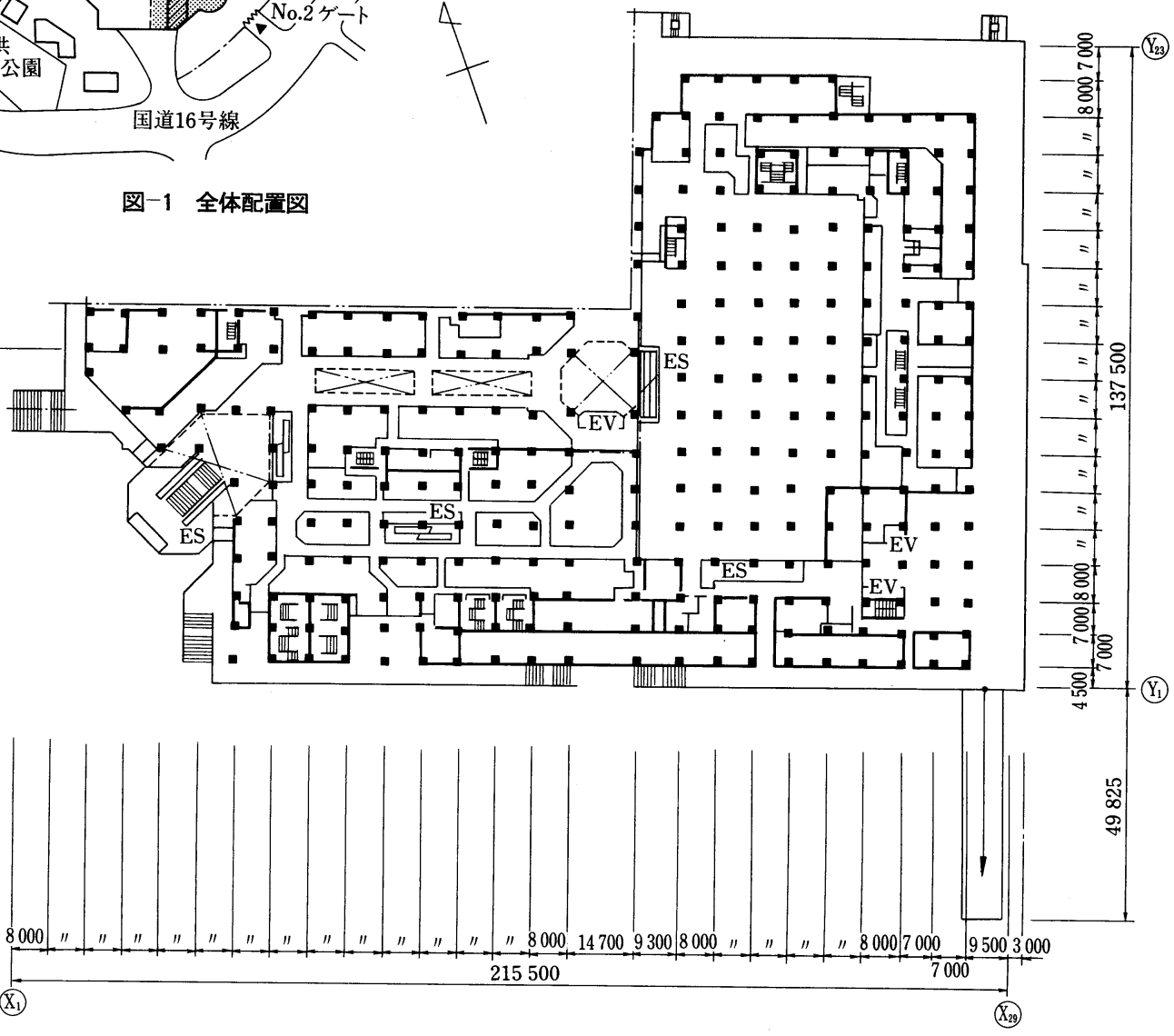

図-2 基準階平面図

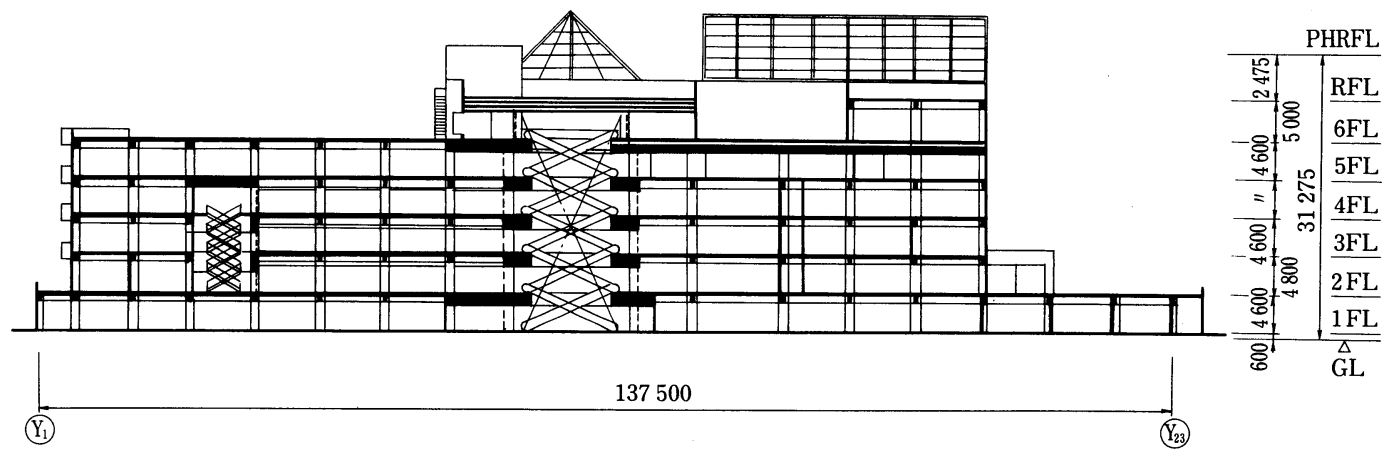

図-3 立面図 


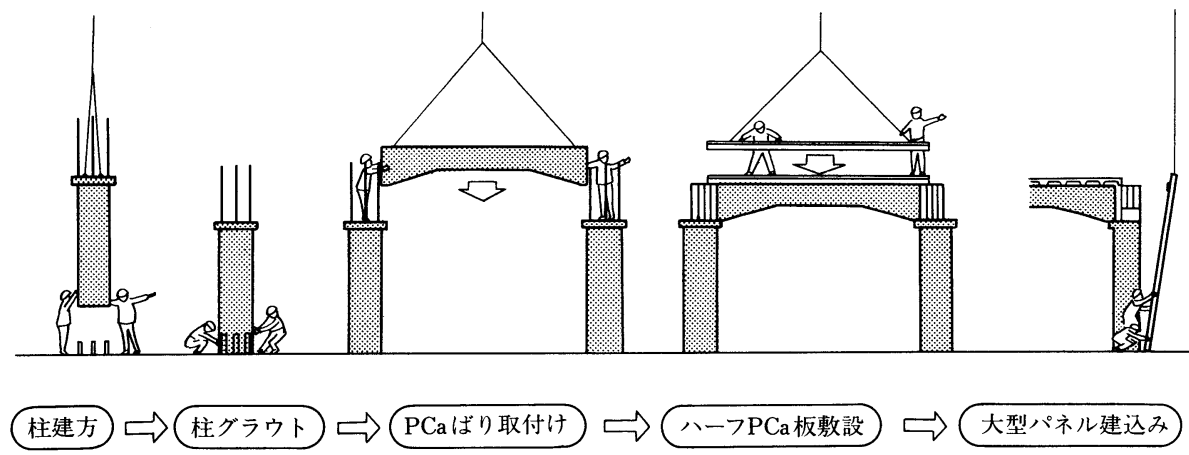

図-4 建て方順序

などによって工法を変える。

建て方手順を図-4, 写真 -2 , 写真 -3 に示す。柱はは り下までを $\mathrm{PCa}$ 化し, 脚部には主筋接合用のスリーブ を内蔵している。この柱を床上から突き出した柱主筋位

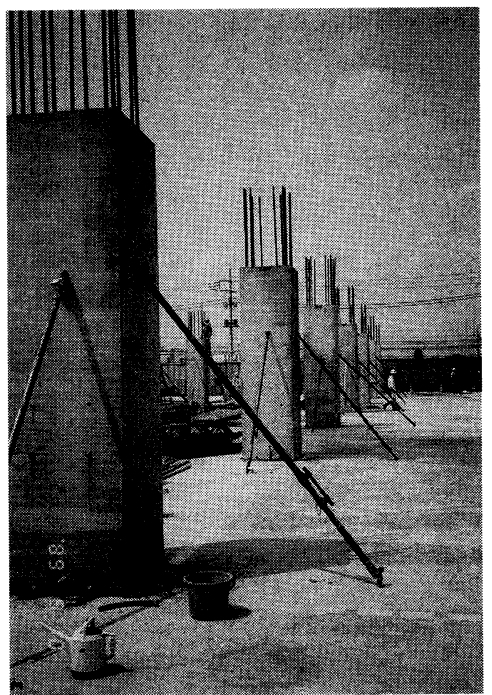

写真-2 PCa 柱の建て方状況

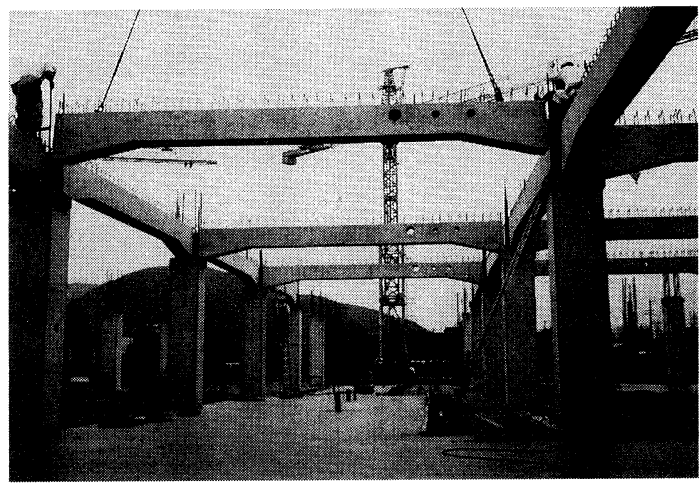

写真-3 PCa ばりの取付け状況
置に設置し，主筋接合用のスリーブ内に無収縮モルタル をグラウトし，柱の建て方が完了する (写真 -2$)$ 。

この柱の上に断面のうちスラブ下までを $\mathrm{PCa}$ 化した はりを設置し (写真 -3$),$ はり上にハーフ $\mathrm{PCa}$ 板を設 置, はり上面, スラブ面上面, パネルゾーンのコンク リートを打設して一体とする。本工法はこの手順を繰り 返して建物を構築する積層工法である。

本工法は $\mathrm{RC}$ 構造における大型店埔の施工法を対象 として開発された工法で, その後, 学校, 病院, 倉庫, 住宅などへと適用範囲を拡大している。部材製造, 運 搬，建て方システムなども標準化された部分が多く，大 幅な工期の短縮と，省力化がはかれるとともに現場作業 の減少と, 工期短縮により建設地周辺に及ぼす騒音, 振 動や工事車両の交通量が大幅に減少するという特徴を有

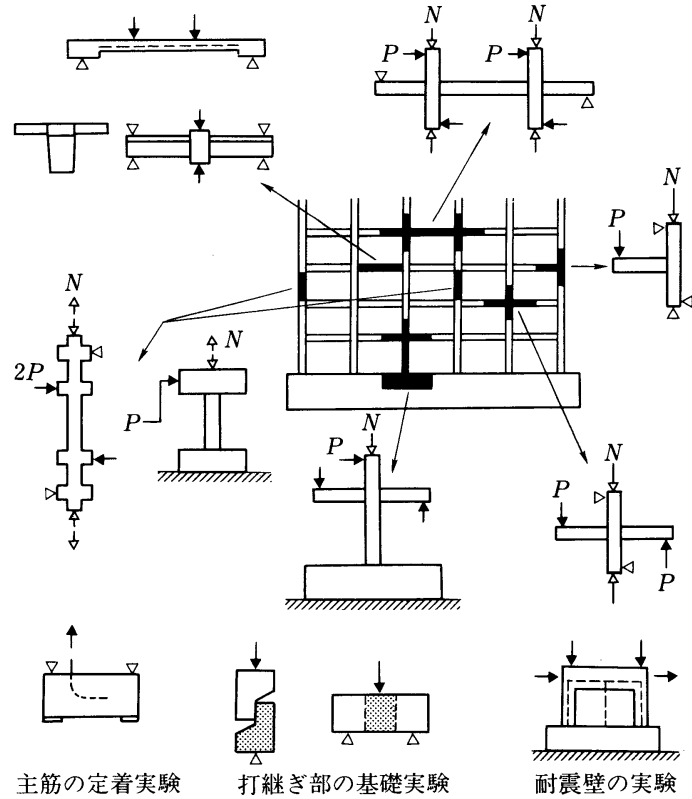

図-5 構造性能確認部位 
している。

本工法の構造性能については図-5に示すような部位 について, 接合部を含む部材実験および施工実験を繰り 返し行っている。これらの実験結果についてはすでに多

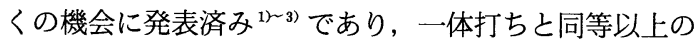
性能を有していることが確認されている。

\section{2 本工事での改良点}

PCa 工法は一般的に構造体の構築方法を対象として 開発された工法が多く, FRPC工法も同様であった。

今回, 当工事への採用にあたって, 顧客の二ーズ, 設 計側, 工事および部材生産側それぞれの立場から要求さ れる事柄について問題点を整理し, 従来の FRPC 工法 に対して改良案の検討を行った。

また, 改良案については当工事の施工には直接反映で きない工法であっても, 試験的に実施することにより将 来的可能性を追求していくことにした。

本プロジェクトで抽出されたテーマは以下であった。

(1) 部材生産の効率化

・サイト工場生産による製造コストの低減

・部材断面および形状の標準化, 部材種別の削減

・簡易型わくによる製造

(2) 建て方システムの改善

・揚重機の削減

・部材供給方法 (小運搬) の検討

・部材の軽量化

(3) 大スパンはりの構造性能と施工方法

- SRC はりの PCa 化

・プレストレス部材の併用

(4) 耐震壁の $\mathrm{PCa}$ 化

(5) 非構造部材の $\mathrm{PCa}$ 化

(6) 部材接合方法の改善

(7) 設備機器のユニット化, 先付け方法

(8) 品質管理方法の合理化

\section{4. 施工}

改善案の検討は工事を進めながら行ったものも多く, 当工事においては, 構造的に設計变更できなかった項目 や, 短期間の検討では期待した効果が得られなかった項 目もある。

本報告は, 改善項目のうち施工の合理化に対して成果 の得られた工法について, 主に(1)の部材生産における歩 掛りの分析結果を紹介し，その他(4)，(5)，8について述 べる。

\subsection{PCa 部材の製造}

$\mathrm{PCa}$ 部材の製造は, これまで固定工場で行うのが一 般的であったが, 本建物は規模が大きく, PCa 部材に 用いるコンクリートのみでも 1 万 $1000 \mathrm{~m}^{3}$ 以上と多
く, 工期の面で外注工場 1 社では生産能力が不足するこ とが予想されたため, 建物を平面的に 2 分割し, 部材製 造をサイト工場と外注工場（固定工場）とでほぼ同数と なるように計画した。サイト工場と固定工場を併用する 場合，柱，はり部材などを部位別に区分し，1 か所で同 一部材を製造するほうが経済的には有利となるが，工事 の進捗に支障をきたさないこと, 精度, 強度などの品質 管理について責任体制を明確にすることなどを考慮して サイト工場と固定工場の製造区分を工区別とした。

（1）サイト工場の概要

(1) サイト工場のレイアウトを図-6に示す。主な機 械設備は門形クレーン $2.8 \mathrm{t}$ を 2 台, $10 \mathrm{t}$ を 1 台, 鉄筋 加工機 3 台, 切断機 2 台である。

(2) コンクリートの養生は, ジェットヒー夕を併用し たシート養生とし, 脱型強度 $100 \mathrm{kgf} / \mathrm{cm}^{2}$ を確保する よう計画した。なお，コンクリートは，早強セメントを 使用した。

(3) ストック数は最大で約 350〜380 ピースとなるた め, サイト工場のストックヤードで 180〜230ピースス トックし, 不足分は順次建て方エリアに小運搬した。

(2) 部材数量および生産規模

サイト工場と固定工場の製造部材数量と設置した型わ く数を表-1 に示す。また, サイト工場と固定工場にお ける月別生産数量と部材種別ごとの生産歩掛りを表-2, 表-3に示す。

部材製造の労務歩掛りはサイト工場が $1.00 \mathrm{~m}^{3} /$ 人・

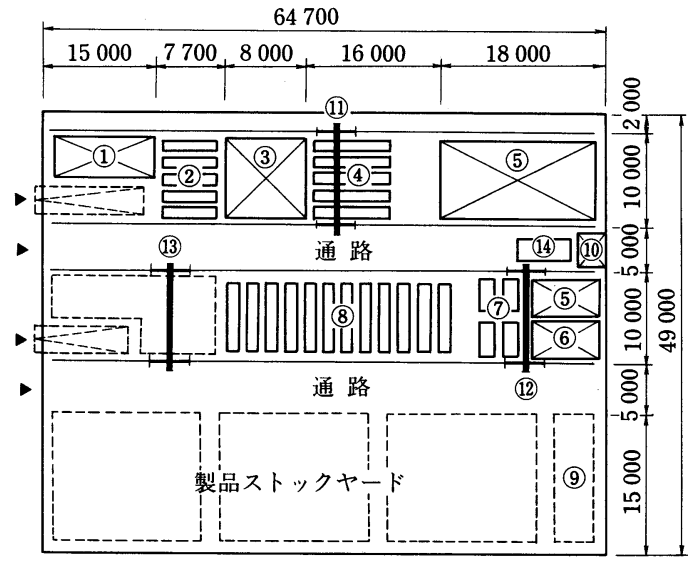

(1) 鉄筋 (生材) 置場

(2) 鉄筋加工ヤード

(3) 加工鉄筋仮置場

(4) 鉄筋組立ヤード

(5) 組立鉄筋仮置場

(6) 柱筋組立ヤード

(7) コンクリート打 設ヤード(柱)
(8) コンクリート打設ヤード(はり)

(9) 型わく仮置ヤード

(10) 雑材置場

(11) 門型クレーン $(2.8 \mathrm{t})(\mathrm{No} .1)$

(12) 門型クレーン $(2.8 \mathrm{t})($ No.2)

(13) 門型クレーン (10t) (No.3)

(14) ユニック車 (組立鉄筋移動)
図-6 サイト工場平面図 
表-1 部材製造数量および型わく数

\begin{tabular}{|c|c|c|c|c|}
\hline & \multicolumn{2}{|c|}{ サイト工場 } & \multicolumn{2}{|c|}{ 固 定 工 場 } \\
\hline & 部 材数 量 & 型わく数 & 部材数量 & 型わく数 \\
\hline (1)地 中ばり & 209 ピース & 8 わく & 185 ピース & 6 わく \\
\hline 柱 & 452 & 4 & 424 & 5 \\
\hline (3)大 ば り & 1027 & 12 & 1181 & 13 \\
\hline (4)小 ば り & 202 & 2 & 182 & 2 \\
\hline (5)そ の 他 & 22 & - & 7 & - \\
\hline 合計 & 1912 & 26 & 1979 & 26 \\
\hline
\end{tabular}

表-2 月別部材製作歩掛り

\begin{tabular}{|c|c|c|c|c|c|c|c|c|c|c|c|c|c|c|}
\hline & \multirow{2}{*}{ 諸 元 } & \multicolumn{3}{|c|}{1989 年 } & \multicolumn{9}{|c|}{1990 年 } & \multirow{2}{*}{$\begin{array}{ll}\text { 拿 計 } & \text { 均) }\end{array}$} \\
\hline & & 10 月 & 11 & 12 & 1 & 2 & 3 & 4 & 5 & 6 & 7 & 8 & 9 & \\
\hline \multirow{4}{*}{$\begin{array}{l}\text { サ } \\
\text { イ } \\
\text { 卜 } \\
\text { 工 } \\
\text { 場 }\end{array}$} & 延 作 業 員 & 205 & 430 & 402 & 341 & 449 & 531 & 462 & 389 & 462 & 512 & 327 & 303 & 4813 \\
\hline & 部 材 本 数 & 24 & 148 & 42 & 80 & 152 & 225 & 260 & 219 & 254 & 344 & 156 & 8 & 1912 \\
\hline & $\begin{array}{c}\text { コンクリート } \\
\text { 歩 } \\
\text { 掛 } \\
\end{array}$ & $\begin{array}{r}101 \\
0.49\end{array}$ & $\begin{array}{r}603 \\
1.47\end{array}$ & $\begin{array}{r}161 \\
0.40\end{array}$ & $\begin{array}{r}202 \\
0.59\end{array}$ & $\begin{array}{r}371 \\
0.83\end{array}$ & $\begin{array}{r}512 \\
0.96\end{array}$ & $\begin{array}{r}583 \\
1.26\end{array}$ & $\begin{array}{r}505 \\
1.30\end{array}$ & $\begin{array}{r}571 \\
1.24\end{array}$ & $\begin{array}{r}775 \\
1.51\end{array}$ & $\begin{array}{r}386 \\
1.18\end{array}$ & $\begin{array}{r}26 \\
0.08\end{array}$ & $\begin{array}{l}4796 \\
(1.00)\end{array}$ \\
\hline & 管 理 者 数 & 36 & 78 & 69 & 66 & 72 & 81 & 90 & 88 & 92 & 104 & 84 & 24 & 884 \\
\hline \multirow{2}{*}{ 固 } & 延 作 業 員 & 166 & 376 & 132 & 96 & 480 & 843 & 670 & 534 & 787 & 742 & 159 & - & 4985 \\
\hline & 部 材 本 数 & 71 & 95 & 19 & 6 & 179 & 353 & 317 & 267 & 291 & 298 & 83 & - & 1979 \\
\hline \multirow{2}{*}{$\begin{array}{l}\text { 工 } \\
\text { 場 }\end{array}$} & $\underset{\text { 歩 }}{\text { コン掛 }}$ & $\begin{array}{r}290 \\
1.75\end{array}$ & $\begin{array}{r}388 \\
1.03\end{array}$ & $\begin{array}{r}78 \\
0.59\end{array}$ & $\begin{array}{r}13 \\
0.14\end{array}$ & $\begin{array}{r}378 \\
0.79\end{array}$ & $\begin{array}{r}758 \\
0.90\end{array}$ & $\begin{array}{r}681 \\
1.02\end{array}$ & $\begin{array}{r}570 \\
1.07\end{array}$ & $\begin{array}{r}639 \\
0.81\end{array}$ & $\begin{array}{r}669 \\
0.90\end{array}$ & $\begin{array}{r}179 \\
1.13\end{array}$ & $\begin{array}{l}- \\
-\end{array}$ & $\begin{array}{l}4640 \\
(0.93)\end{array}$ \\
\hline & 管 理 者 数 & 38 & 54 & 50 & 46 & 52 & 58 & 50 & 48 & 54 & 52 & 48 & - & 550 \\
\hline
\end{tabular}

表-3 生産歩掛り

\begin{tabular}{c|r|c|c|c|c}
\hline & 生 産 数 量 & 鉄筋加工 & 型わくコンクリート打設 & 移動小運搬 & 生産歩掛り \\
\hline 地中ばり & 209 ピース & 113 人 & 493 人 & 116 人 & 3.5 人/ピース \\
\hline 柱 & 452 ピース & 48 人 & 624 人 & 59 人 & 1.6 人/ピース \\
\hline 大 ば り & 1027 ピース & 346 人 & 2108 人 & 525 人 & 2.9 人/ピース \\
\hline 小ば り & 202 ピース & 39 人 & 232 人 & 36 人 & 1.5 人/ピース \\
\hline その 他 & 22 ピース & 11 人 & 52 人 & 11 人 & 3.4 人/ピース \\
\hline 合 計 & 1912 ピース & 557 人 & 3509 人 & 747 人 & 2.5 人/ピース \\
\hline
\end{tabular}

日, 固定工場では $0.930 \mathrm{~m}^{3}$ /人・日であるが, 一部材の 製造に要した労務量は両工場ともほぼ 2.52 人・日/本と 同じであった。

なお, サイト工場の所要人員数には, 工場設備の設置 および撤去に要した人員数も含まれており，これらの作 業を除外するとサイト工場の方が生産性が良かったと言 える。これはサイト工場の場合, 製造ラインを特定の部 材専用に設置したため, 作業性の向上が図れたためと考 えられる。

管理者の投入数については，固定工場の方が少ない結 果となっている。固定工場の場合，本工事に必要な部材 製造の管理と同時に, 複数工事への部材も製造してお
り，これらの製造管理を同時に行っている。今回のデー 夕は固定工場における管理者数を本工事の部材と他工事 への部材の数量比率で配分した值である。

(3) 生産コスト

サイト工場におけるトータルの生産コストは固定工場 の $87 \%$ であった。

サイト工場と固定工場とで大きく異なる項目は，固定 費と運搬費であろう。したがって，サイト工場で製造し たことによるトータル生産コストのコストダウン率 13 \%の要因は，固定費と運搬費によるものと考えられ る。

サイト工場における生産コストの構成比率を図-7に 


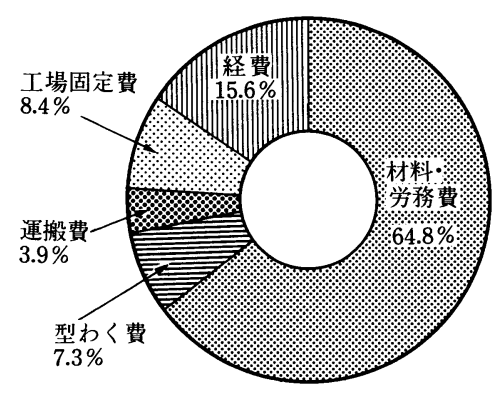

図-7 生産コストの構成比率

示す。

固定工場では，本工事の部材製造時においても，同時 に多くの他部材を製造している。したがって，構成比率 の算定にあたって, 当工事分としての一般経費, 工場固 定費を明確に区別できなかったが，一般的に固定費の割 合は 15 20\% である。

サイト工場の計画にあたっては，もっと簡便なシステ ムもあるが，本工事は製造部材数が多く，期間も 12 か 月を要したため，十分な設備投資を行った。しかし，図 -7 で分かるように，固定費は $8.7 \%$ にすぎない。

なお，固定費には，サイト工場設置費，クレーン等の 機械損料, 動力, 用水費, 宿舎等の費用を含む。

\section{2 外周部車路の $\mathrm{PCa}$ 化}

本建物は, 屋上が駐車場である。このような場合, 外 周部車路の部分は通常, 在来工法で施工する場合が多 かったが，この部分を $\mathrm{PCa}$ 化することにより，省力と 工期の短縮が図られるとともに，車路の早期利用が可能 となり, あと工程の設備, 仕上げ工事への支援効果が大 きかった。

\section{3 内部間仕切り壁の $\mathrm{PCa}$ 化}

$\mathrm{PCa}$ 工法において工期短縮，低コスト化をはかるた めには，より $\mathrm{PCa}$ 化率を高めることである。とくに， 耐震壁の PCa 化は重要な課題であるが，すでに設計が 完了した後の変更が困難であり, 今回は構造的な制約の 少ない帳壁の PCa 化について検討した。

壁の製作は帳壁の取り付く位置の床面で行い，柱，は りの建込みと同時に, 建て起こして取り付ける方式とし た。接合方法は図-8に示すように柱, はりに溝をつ け，柱を建てたのち，落とし込む方式とした。

この工法の採用により, 在来のコンクリート壁による 間仕切り壁取付け作業に対して, コストダウン率 $20 \%$, 省力化率 70\% の効果が認められた。さらに, 柱, はり 部材の建て方と同時に間仕切り壁もできていくため, あ と工程を考えると, 工期の短縮にはいちじるしい勃果が あった。
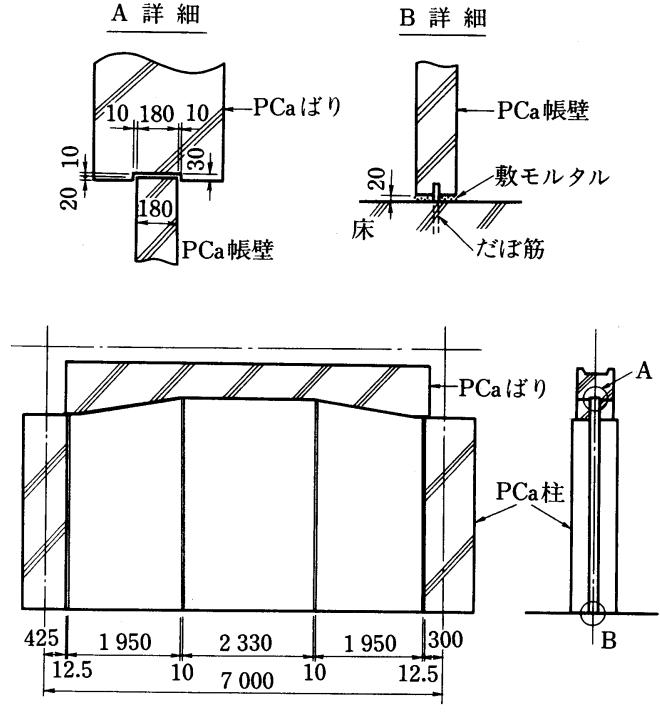

図-8 帳壁 PCa 化のディテール

\section{4 避難バルコニーの PCa 化}

大型店舗の場合, 避難バルコニーの設置が義務付けら れている。この避難バルコニーは集合住宅のように 1 階 から最上階まですべてに必要ではなく，店舗レイアウト にもよるが，中間階のみに取り付く場合が多い。

したがって，バルコニー取付け用の外部足場が必要で あり，躯体工事のネックとなっている。この問題を解決 する方法として，鉄骨によるあと付けが広く採用されて いるが, さびの問題がある。

今回行った改善案は, 写真 -4 に示すようにサイト工 場で立体的に製作し, 躯体完了後 PC 鋼棒で緊結する方 法とした。

今回の工法は現設計を変更することなく取り組んだた め, デザイン的な制約もあり，全バルコニーのうち $1 / 3$ のみについて試験的に行い, コスト的には在来工法であ る場所打ちと比較して $20 〜 30 \%$ 割高となった。

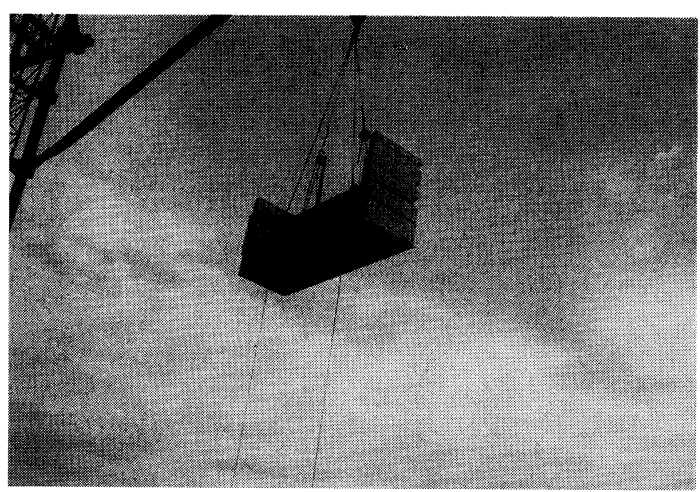

写真-4ＰCa バルコニー 
しかし, 外部無足場でも施工が可能であり, 今後計画 の段階から, 形状, 取付け位置などを考慮した設計を行 えば, 工期短縮, 省力化に対して有効な工法であるとの 見通しを得た。

\section{5. 品質管理について}

PCa 工法は一定の品質を有する部材が安定して供給 されるため，現場管理についてはポイントを絞り込んで 品質管理ができるという長所がある。現場管理のポイン 卜は大きく分けて 2 点ある。

\section{1 ひびわれの管理}

1 つは部材のひびわれに対する注意である。 $\mathrm{PCa} 工$ 法の開発にあたって，建物の性能は在来工法と同等以上
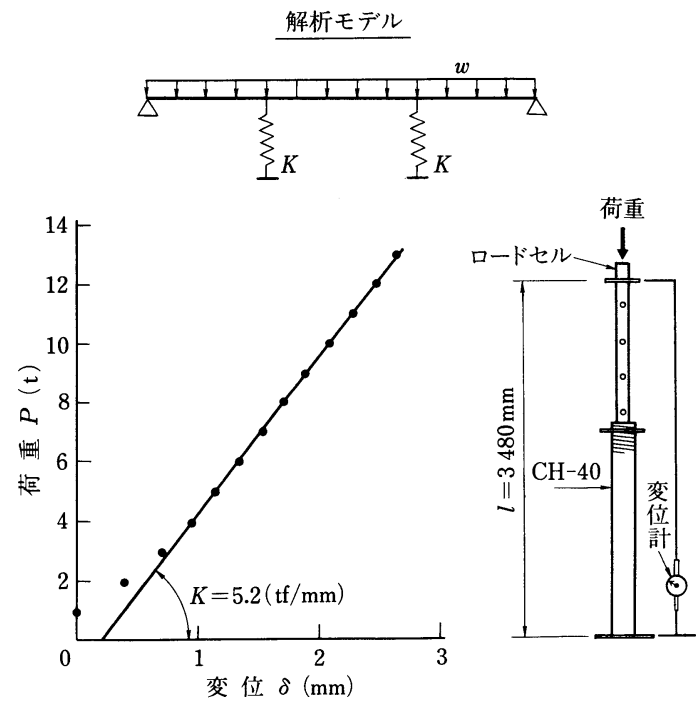

図-9（a） 強力サポートの荷重-変位曲線と解析モデル

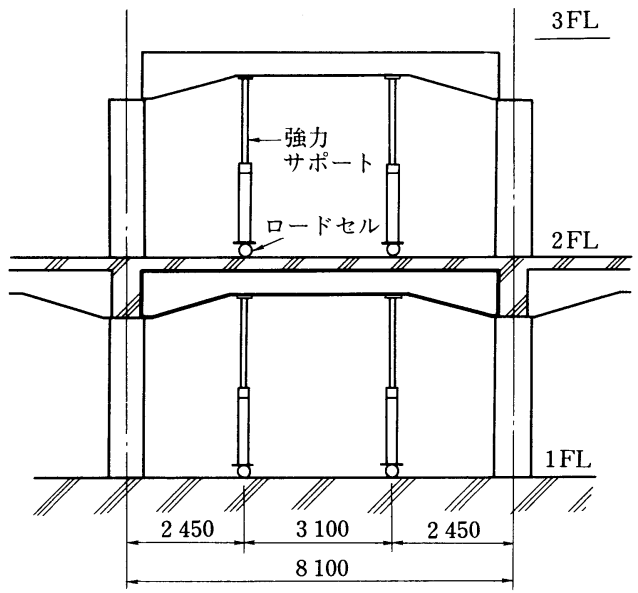

図-9（b） 荷重測定位置および荷重条件
であることが前提であるが，部材の組立て手順によって 各部材の仮設時の応力は在来工法とは多少異なる。

とくに，はり部材は仮設時は半製品の断面である。本 工法では床に合成スラブ工法を採用しており, 合成スラ ブを支持する $\mathrm{PCa}$ はりは施工中はひびわれ防止のため はり下にサポートが必要である。しかし, サポートの存 置期間については明確な規定がなく，設計上では少なく とも 2 層分は必要であるとされていた。

本工事においては, 使用に先立って, 使用するサポー 卜単体の圧縮試験を行い, サポートの軸剛性を求めた。

この試験結果から得られたサポートの剛性を用いて,

図-9 (a)に示すように, 弾性支持された半ばりの曲げ 応力を計算した。計算の結果, 当然のことながら, 4 点 支持の場合よりも弾性支持の方がサポートに作用する荷 重は小さくなる。計算結果を実証するために, 建て方時 にサポート荷重を測定した。測定は図-9（b)に示すよ うに, 標準断面のはり 2 か所, 4 本のサポートにロード セルを取り付けて, 合成スラブの設置, トッピングコン クリート打設, 上階のはり設置, 上階の合成スラブの設 置, 上階のコンクリート打設とそれぞれの工程ごとに 行った。測定の結果, サポート荷重は, 計画当初の略算 で設定した值よりも小さく, 弾性支持条件での計算値と 良く一致していた。

計算結果およびサポート荷重の実測值を検討した結 果, 下階のコンクリートが十分な養生期間が経過した後 であれば，上階の荷重を支持できることが分かったため サポートの設置は直下階のみとした。

なお，本結果は使用するサポートの種類によって弾性 ばねが異なり, また, 下階のコンクリート強度にも影響 するため, 常に 1 層分でよいということではなく, 建物 ごとの検討が必要である。

\section{2 打継ぎ部の管理}

現場における品質管理上, もっとも重要な点は $\mathrm{PCa}$

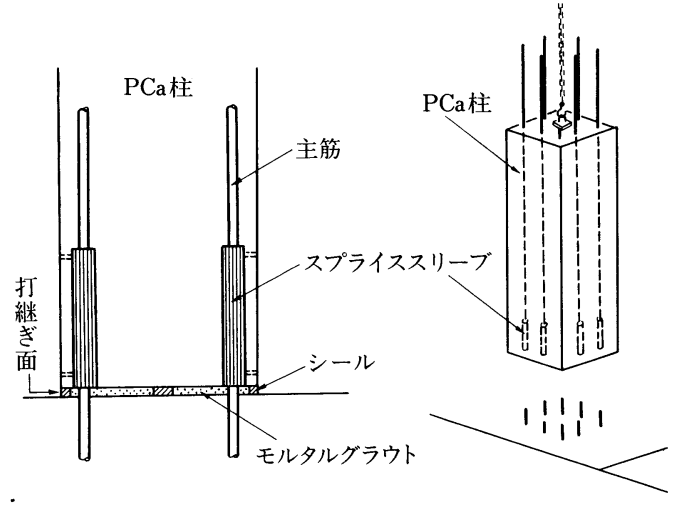

図-10 PCa 柱脚部の施工方法 

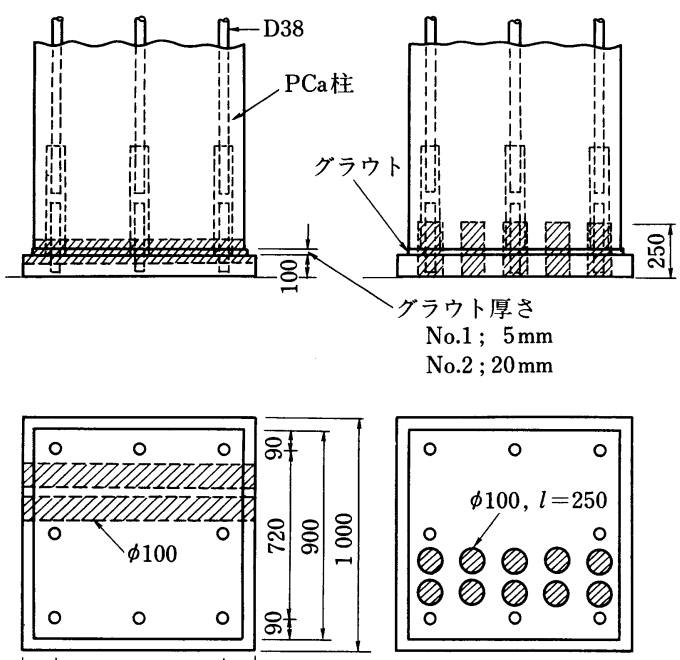

\begin{tabular}{|cc}
90 & 720 \\
\hline+ & 900 \\
\hline & 1000 \\
\hline
\end{tabular}

図-11 施工実験用試験体およびコア採取位置

部材とあと打ちコンクリートとの一体性である。

また, PCa 柱は図-10 に示すような施工方法が一般 的であり, 軸力を確実に伝達するために, この部分はと くに入念に施工しなければならない。

本工事では, 床面と PCa 柱の間は約 $15 \mathrm{~mm}$ で, こ の間に無収縮モルタルをグラウトする方式とした。柱脚 部の施工性については工法開発の段階から, 実物大の柱 についてグラウトの施工実験を行い, 全面をコアボーリ ングし, モルタルの粘性度とすきまの関係など, その充 填性について検討を繰り返し行ってきた。図一11に試験 体の一例とボーリング位置を示す。

本建物においても, モルタルの充填性を確認するため にPCa 柱の脚部をコアボーリングした。

通常の建物の場合は, 柱が床面から立ち上がっている 場合が多く，ボーリングすることはかなり困難である。 今回, 飲食店が入るため床が 1 段下がった部分があり, また, 耐震壁があり, ボーリングしても構造的に大きな 影響がないと思われる位置からコアを抜き取った。

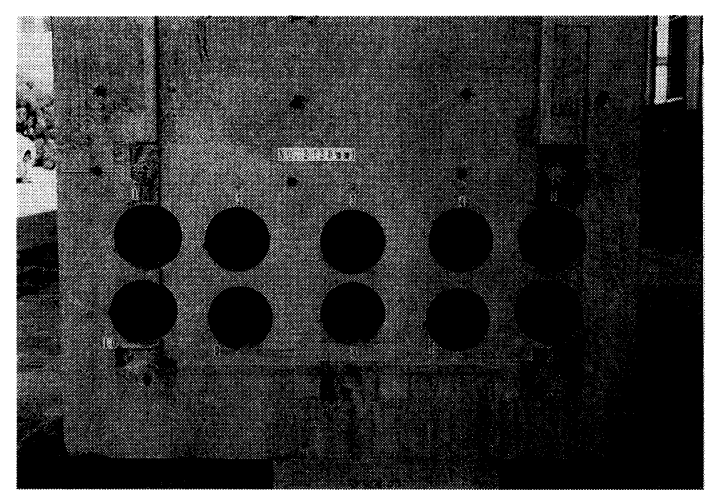

写真 -5 柱脚グラウトの調查状況

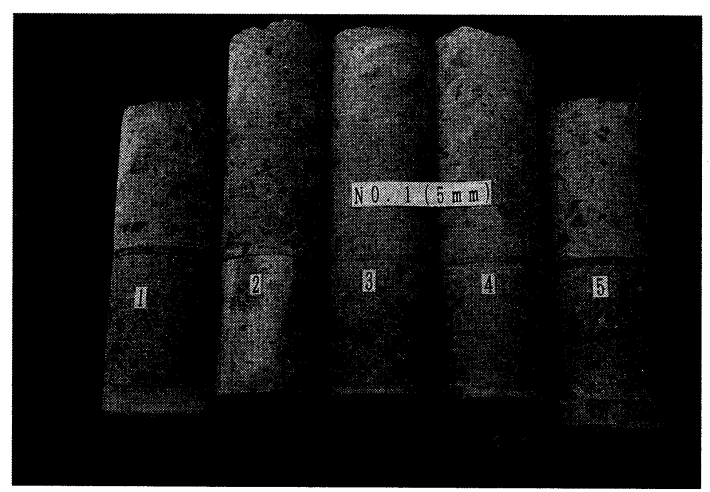

写真-6 グラウト部の拔取りコアの状態 (コア径 $100 \mathrm{~mm}$ )

コアは帯筋を切断しないように $48 \mathrm{~mm}$ とし, 6 か所 から各 2 本, 計 12 本採取した。実大試験での拔取り位 置とコアの状態, 実施建物から抜き取ったコアの一部を 写真-5 写真-7 に示す。

写真で分かるように充填性は良く，陥はほとんど見 られなかった。

\section{6. おわりに}

最近，プレキャスト部材を用いた工法開発は RC 造 のみではなく, SRC 造や混合構造にも採用されるよう になり，適用範囲はますます拡大されつつある。
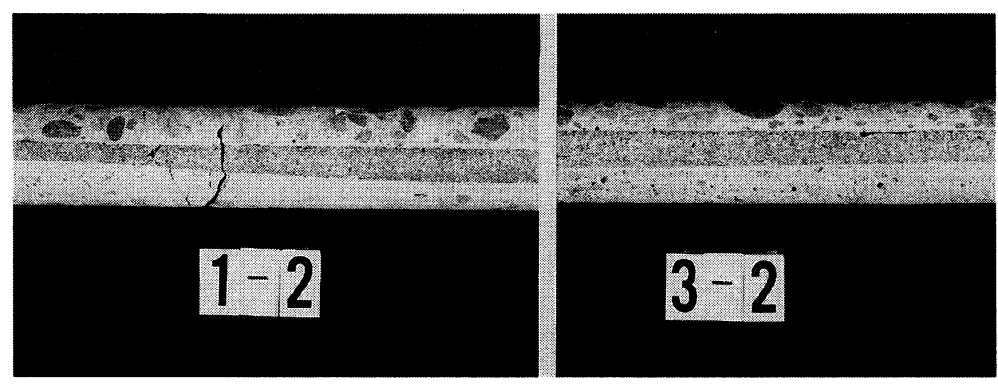

写真-7 実施工柱接合面より抜き取ったコアの状況 (コア径 $48 \mathrm{~mm}$ ) 
プレキャスト部材は, 高品質, 高強度部材の供給が容 易であり, 部材相互の接合についても新材料の利用など によって, 従来の性能よりも優れた工法が開発されつつ ある。さらに, 最近, 盛んになってきた建設ロボット, 自動化施工などの開発においても, PCa 工法は重要な 位置を占めている。

今回行った改善案は, ある面でコストを度外視して, 技術的な可能性の追求に重点を置き, それなりに成果が あったと考えている。

また, 実施に移せなかったテーマについても, 今後実 験, 試験施工を繰り返し, PCa 技術を躯体工法のみで はなく, 構造, 意匠, 設備計画までを含めた建築生産シ ステムに対してその位置付けを検討し, 新しい生産シス テムの一環として発展するように努力したい。
参考文 献

1）狩野芳一・吉野次彦 : 架構式プレキャストコンクリー ト,コンクリート工学, Vol. 25, Nol. 3. 1987. 3

2）吉野次彦ほか：プレキャスト鉄筋コンクリートラーメン 構造の開発研究 (その 1 その 9), 日本建築学会大会講 演梗概集, 1980. 9〜1985. 10

3）吉野・三瓶・佐々木 : プレキャスト鉄筋コンクリート柱 の力学的挙動に関する研究, 日本建築学会大会講演梗概 集, 1990.10

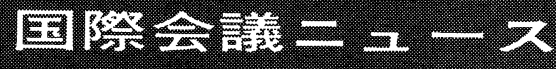

\section{第 9 回国際建設ロボットシンポジゥム}

日 時: 1992 年 6 月 3 日〜 5 日

場 所: 東京 (日本)

主 催: 日本産業用ロボット工業会ほか

後 援: 日本コンクリート工学協会ほか

内 容 : A. 建設ロボットの現状と将来

(1) 建設現場におけるロボットのニーズ

（2）建設ロボット開発をめぐる社会的課題

（3）設計・施工情報のフィードバック

(4) ロボット化施工のための設計問題

(5) 労㗢者とロボットのインタフェース

(6) ロボットをめぐる研究・開発動向

(7) その他

B . ロボット化施工における計画・管理技術

（1）建設ロボットの経済性分析

(2) 工事計画・管理手法

(3) コンピュー夕利用技術,グラフィクス,

\section{$\mathrm{CAD} / \mathrm{CAM}$}

（4）情報化施工

(5) 知識工学, エキスパートシステム

(6) ロジスティクス

(7) その他

C . 建設ロボットの要素技術

（1）センサ, 走行, 作動特性

(2) エンドエフェクタ

(3) 教示方法
（4）情報伝達，遠隔制御

(5) ロボットの機構

（6）ロボット化施工の品質と生産性

(7) その他

D. 工事現場における建設ロボットの適用事 例

（1）掘削, 加工・組立，仕上，ハンドリングロ ボット

(2) 搬送ロボット

(3) 無人車輛システム (AVS)

(4) 検査 (計測・探査・診断) ロボット

(5) 解体ロボット

(6) その他

論文申込：‘91 年 11 月 15 日までに 200 400 語の英文 概要とテーマ分類名, 氏名, 所属, 連絡先 をA 4 用紙 1 枚にまとめ, 下記まで送付 のこと

連 絡 先: $=105$ 東京都港区芝公園 3-5-8 機械振 興会館

（社）日本産業用ロボット工業会内 第 9 回国際建設ロボットシンポジウ 么事務局

Tel. (03) 3434-2919

Fax.(03) 3578-1404 